\title{
A computarized warning system for fire blight control
}

\author{
C Jacquart-Romon 1, JP Paulin ${ }^{*}$ \\ 1 Météo-France, Subdivision d'Agrométéorologie, 2, Avenue Rapp, 75341 Paris Cedex 07; \\ 2 INRA, Station de Pathologie Végétale, Rue Georges Morel, 49070 Beaucouzé, France
}

(Received 12 February 1991; accepted 7 april 1991)

\begin{abstract}
Summary - A warning system for the control of fire blight in pear and apple has been described. It is based upon the determination at the local level of a climatic potential (CP), and an inoculum potential (IP). These potentials are combined in order to estimate an overall level of risk. A recommended control measure is associated with this risk. Among the inputs required, climatic data, forecast of certain climatic parameters and precise information about the disease situation in the plot and its surroundings are essential. The warning system is computerized, and has been devised for use with an IBM-PC personal microcomputer; its availability to growers and plant protection services is presently under study.
\end{abstract}

bacterial disease $/$ warning system $/$ Malus $=$ apple $/$ Pyrus communis $=$ pear $/$ Erwinia amylovora

Résumé - Un système d'avertissement informatisé pour la lutte contre le feu bactérien. La lutte contre le feu bactérien est rendue particulièrement difficile par l'irrégularité des infections provoquées par la bactérie responsable (E amylovora). Dans une semblable situation, un système d'avertissement constitue une aide déterminante. Le système proposé prend en compte au niveau de la parcelle 2 des facteurs de la variabilité de la maladie : le climat et le niveau d'inoculum. Un potentiel climatique (PC) (tableaux I, II, III) est déterminé en fonction du climat auquel le verger a été soumis depuis le fer février de l'année en cours et à partir des prévisions du temps à $2 j$ (températures, pluie). Un potentiel d'inoculum (PI) (tableaux $V, V, V I$ ) est établi notamment d'après les connaissances du développement local de la maladie dans le passé, et de son activité observée actuelle. Il est tenu compte également de la phénologie de l'hôte; 3 périodes sont considérées : préfloraison (stades $D$ à $E_{2}$ ), floraison ( $E_{2}$ à $G$ ), postfloraison (après le stade G). En postfloraison, l'état physiologique de l'hôte doit être précisé (croissance, présence de floraison d'été). La combinaison de ces potentiels, spécifique à chacune de ces périodes permet la définition d'un conseil de lutte, gradué en 3 niveaux (ne pas intervenir, réaliser une visite du verger, traiter chimiquement) (tableaux VI, VII, VIII). Ce système, d'utilisation simple, est prévu pour fonctionner sur un micro-ordinateur compatible PC. II demande, pour donner satisfaction, que plusieurs conditions soient réunies : en particulier une étude climatique préalable de la zone est nécessaire, de même que la disponibilité de prévisions météorologiques adaptées. De plus, une connaissance locale des conditions dans lesquelles se développe le feu bactérien (sensibilité variétale, vecteurs, plantes hôtes secondaires, fertilisation) reste indispensable. Les 3 produits utilisables dans la lutte en France (fluméquine, cuivre, phosétylaluminium) peuvent être associés à l'utilisation de ce système d'avertissement, dont la diffusion auprès des arboriculteurs et des services de la protection des végétaux est en cours d'étude.

bactériose $/$ lutte raisonnée $/$ Malus $=$ pomme $/$ Pyrus communis $=$ poire $/$ Erwinia amylovora

\section{INTRODUCTION}

One of the obstacles to a satisfactory control of bacterial diseases is the lack of regularity of infections over the years. This is particularly true in the case of fire blight caused by Erwinia amylovora, a classical bacterial disease of pear, apple and ornamental (Pomoideae) in Europe and North America. A warning system aimed at providing in a help in the adjustment of control measures is probably one of the answers to this specific difficulty.

It has been shown by several authors in the United States and in Europe (Mills, 1955; Powell,

* Correspondence and reprints 
1965; Thomson et al, 1975; Billing, 1976, 1978a) that climatic factors are of key importance in determining the severity of fire blight for a given year. Several approaches have been proposed or suggested which attempt to describe the activity of the disease from the assessment of several factors (field, plant, and climatic factors) (Thomson et al, 1977; Billing, 1978b, 1988; Beer et al, 1984; Billing and Paulin, 1990; Steiner, 1990a, b).

Approaches proposed by Billing (Billing, 1979, 1980a, b), though relatively simple to use are probably the most comprehensive. In several countries Billing's original system (BOS) (Billing, 1984) has been repeatedly shown to give satisfactory results, either used on a day-to-day basis, or applied to past weather and disease data (Billing, 1980a; Meijneke and van Teylingen, 1981; Paulin et al, 1983; Bazzi et al, 1984; Sobiczewski, 1984; Bonn, 1987).

We describe here a warning system for fire blight, based on the combination of a climatic potential (CP) with an inoculum potential (IP). CP is determined by data derived from BOS, associated with forecasts of meteorological parameters; IP is estimated mainly from knowledge of the local past history of the disease. A report on a preliminary version of this system has already been published (Jacquart-Romon et al, 1987).

\section{DESCRIPTION OF THE WARNING SYSTEM}

\section{Inputs}

\section{Climatic data}

The compiled climatic data needed are those required for BOS, and run from February 1st of the current year: daily minimal and maximal temperatures, and daily rainfall.

\section{Weather forecasts}

The following data regarding weather are required for the actual day of interrogation and for the day after: minimal and maximal daily temperatures; daily occurrence of rain; daily amount of rainfall, with respect to the $2.5 \mathrm{~mm}$ threshold: rainfall of $\geq 2.5 \mathrm{~mm}$, or rainfall of $<2.5 \mathrm{~mm}$; daily occurrence of a storm. In this context, a storm in- cludes any climatic event likely to provoke some damage on aerial parts of fruit trees; strong winds and/or heavy rain and hail are therefore included within the storm category.

\section{Plant growth and development}

The growing period of pear or apple trees has been divided into 3 stages. On the date of interrogation, the input is as follows: the indication of the stage of development: phenological stages $D, E_{2}$ or $G$ (Fleckinger, 1945), growth status of the shoots (ie presence of succulent shoots), occurrence of secondary blossoms in the orchard (at least $25 \%$ of the trees show at least 1 blossom).

\section{Activity of the disease}

The available inoculum is assumed to be related to the status and proximity of symptoms of fire blight. The inputs are related to the nature of the symptoms, in time: old or recent lesions, and in space: symptoms detected in the area, in the orchard, or in the precise plot to be protected against fire blight. The term "orchard" refers to a group of plots belonging to the same farm, close to each other, and managed in a similar way by the same team of workers. A "plot" is a cluster of trees usually belonging to the same cultivar, planted in the same field.

An "active lesion" is a symptom in which the bacteria are multiplying rapidly. Because this activity is climate-dependent, some climatic inputs are taken into account during certain periods (see below).

\section{Outputs}

The warning system is intended for use between the 1st of February and the end of July. Before phenological stage $D$ the output is limited to a climatic analysis of the potential for fire blight activity. After stage $D$, additional information is provided on adequate control measures; 3 types of advice, adjusted for the local situation, are issued by the software: i), no action necessary in the plot for the control of fire blight; ii), visit the plot in order to detect (and destroy) expected recent symptoms; iii), apply a suitable spray to prevent new infections (after pruning out of parts showing symptoms). 


\section{EVALUATION OF FIRE BLIGHT RISKS}

\section{Factors involved in evaluation of the risks}

The level of severity of fire blight is the result of the combination of at least 3 types of factors, linked to plant, climate and inoculum.

\section{Plant factors}

The risks of infection differ according to the tree's stage of development. In our warning system, they are considered to appear at stage D. Up to stage $E_{2}$ of flower bud development they remain low, because routes of infection are not easily accessible. During the blossom period (from stage $E_{2}$ to stage $G$ ) they are very high, the natural openings of flowers facilitating introduction of the bacteria into the plant. Afterwards the risks are limited to 2 periods associated with the growth status of the plant: shoot growth, when tips of growing shoots can be infected by the bacteria, and secondary blossom, when open flowers are present on the trees.

The variability of the risks associated with the plant is taken into account in the system that we used as a basis for the calculation of the potential activity of the disease (BOS): different climatic factors are taken into account according to the stage of growth of the plant. This is why the period of susceptibility to fire blight is divided into 3 stages: different data are considered or data are considered differently, during these periods, which are as follows: $i$ ), pre-bloom: from stage $D$ to stage $E_{2}$; ii), blossom period: from stage $E 2$ to stage $G$; iii), post-bloom: after stage $G$.

\section{Climatic factors}

The past climatic data as well as forecasts collected and processed according to BOS are used for a climatic analysis. According to this analysis and to the climatic forecast, a climatic potential (CP) is assessed for the next 2 days. This potential ranges between 1 (low climatic risk) and 4 (high climatic risk). Its determination differs according to the period described above.

During the prebloom period, temperatures play a key role in the increase of the bacterial population in overwintering lesions: water supply is not considered as a limiting factor for bacterial multiplication at this stage. Infections are linked to damaging climatic events (storm). Therefore the aim of control measures is to limit the level of available inoculum. Potential doublings of the bacterial population (PD) and end of incubation periods (I) calculated according to BOS are the basis for the scale of climatic potential (CP) shown in table 1 .

During the blossom period the determination of infection conditions is of the greatest importance: both rain and temperature play an important role. According to Billing (1980a), a day

Table I. Determination of the climatic potential (CP) during prebloom.

Forecast $\quad C P$

None of the following events 1

$\mathrm{PD} \geq 9 \quad 2$

End of I period, or $2 \mathrm{PD} \geq 9$

End of I period and 2 PD $\geq 9$ or storm 4

Table II. Determination of the climatic potential (CP) during bloom.

$\begin{array}{ll}\text { Forecast } & C P\end{array}$

No end of I period

- None of the following events is forecast

$-P D \geq 9$, or storm, or other infection conditions

$-2 P D \geq 9$

- Storm and: $P D \geq 9$ or other infection conditions, or rain $\geq 2.5 \mathrm{~mm}$

3

End of I period $(J-1, J, J+1)$

- No other event foreseen

Rank of I period +2

- One infection condition foreseen

Rank of I period +3 
when one of the following conditions is met is likely to be an infection day: $P D \geq 9 ; P D \geq 3.5$ with rain, rain $\geq 2.5 \mathrm{~mm}$. PD is the potential doubling of Erwinia amylovora in its host according to daily minimal and maximal temperature, when water is not a limiting factor. A storm may favour infection as well, whatever the temperature or amount of rainfall if there is tissue damage. The success of infection depends on the availability of bacteria: this is evaluated by the completion of incubation periods (BOS). The rank of incubation periods (I) during bloom has been pointed out as an indicator for the build up of the inoculum (Jacquart-Romon et al, 1984). The scale of CP during bloom is given in table II.

During the postbloom period, the climatic conditions allowing infection to taken place differ according to the route of infection (shoot or secondary flower). The scale of climatic potential is given in table III.

\section{Inoculum factors}

Records of the disease and of its past history in the area in the orchard and/or in the plot are used as a basis for the estimation of an inoculum potential (IP) (tables IV, V). For the postbloom period, in the case where no symptoms are observed, an IP is derived from the assessment of the climatic potential activity of the disease during the blossom period and the $15 \mathrm{~d}$ preceding interrogation. This is: i) to stress the key role of the activity of the disease during the blossom period on further development of fire blight in the orchard; ii) to take into account the fact that certain weather conditions during bloom can pro-

Table III. Determination of the climatic potential (CP) during postbloom.

\begin{tabular}{lll} 
Plant status & Forecast & $C P$ \\
\hline \multirow{3}{*}{ No shoot growth } & - No storm & 1 \\
& - Storm & 2 \\
Shoot growth & - No rain $\geq 2.5 \mathrm{~mm}$, or storm & 1 \\
& - Rain $\geq 2.5 \mathrm{~mm}$ & 2 \\
& - Storm & 3 \\
Secondary blossom & - No rain, storm, or PD $\geq 9$ & 1 \\
& - Rain $\geq 2.5 \mathrm{~mm}$, or PD $\geq 9$ & 2 \\
& - Storm & 3
\end{tabular}

mote disease activity which could remain undetected for some time, and yet be a source of bacteria for infections.

\section{Decision}

Potentials for climatic and inoculum risks are combined differently during the 3 periods to provide an overall risk. The level or risks determines the type of control measure to be taken. The different combinations of CP with IP for prebloom, bloom and postbloom periods are given in tables VI, VII, VIII, respectively.

Sprays against fire blight must be applied before infection. They are recommended when both infection conditions are forecast, and a high level of inoculum is expected from the observations of symptoms and/or from the climatic conditions.

Visits to the orchards are aimed at cutting out symptoms: they are recommended when symptom expression can be expected from analyses of the risks, so that the grower checks the fire blight situation in his orchard at the proper period, thus avoiding useless and time-consuming surveys.

During bloom, special care is taken if pollinating insects are present: protective sprays are therefore recommended when both symptoms and insect activity are observed in the orchard.

During postbloom, in the case of infection risks due to the presence of secondary blossoms, it may be preferable to remove the flowers if this is economically feasible, instead of using a recommanded spray.

Table IV. Determination of the inoculum potential (IP) during prebloom and blossom period.

Observations

IP

No fire blight in the area

1

Fire blight introduced in the area and:

- Not detected in the orchard the previous year 2

- Detected in the orchard the previous year

3

Fire blight detected this year in the orchard and:

- Disease activity observed before bloom

- Disease activity observed in the close vicinity

of the plot during bloom

- Disease activity observed in the plot during bloom 
Table V. Determination of the inoculum potential (IP) during postbloom.

Young active symptoms not observed during the $15 \mathrm{~d}$ before the day of questioning

- Rank reached during bloom $<2$

and - Rank reached during the last $15 d \geq 2$

- Rank reached during bloom $<2$

and $\quad-$ Rank reached during the last $15 d \geq 2$

- Rank reached during bloom $\geq 2$

and - Rank reached during the last $15 d<2$

- Rank reached during bloom $\geq 2$

and - Rank reached during the last $15 d>2$

Young active symptoms observed in the plot during

the last $15 d$ and removed

Young active symptoms observed in the close vicinity of the plot during the last $15 \mathrm{~d}$ and not removed

Young active symptoms observed in the plot during the last $15 \mathrm{~d}$ and not removed

Table VI. Table of decision during prebloom period.

\section{$C P$}

\begin{tabular}{lllll}
$I P$ & 1 & 2 & 3 & 4 \\
\hline 1 & $\mathrm{~N}$ & $\mathrm{~N}$ & $\mathrm{~N}$ & $\mathrm{~N}$ \\
2 & $\mathrm{~N}$ & $\mathrm{~N}$ & $\mathrm{~N}$ & $\mathrm{~V}$ \\
3 & $\mathrm{~N}$ & $\mathrm{~V}$ & $\mathrm{~V}$ & $\mathrm{~S}$ \\
4 & $\mathrm{~N}$ & $\mathrm{~V}$ & $\mathrm{~S}$ & $\mathrm{~S}$
\end{tabular}

Tables VI, VII, VIII. N: no action required for fire blight control. $\mathrm{V}$ : visit the plot to detect (and remove) symptoms. S: spray with a suitable chemical, ie prebloom: coper compound $100 \mathrm{~g}$ $\mathrm{Cu} \mathrm{hl}^{-1}$; blossom period and postbloom: streptomycin $10 \mathrm{~g} \mathrm{hl}^{-}$ 1, flumequine $30 \mathrm{~g} \mathrm{hl}^{-1}$, phosetyl Al $200 \mathrm{~g} \mathrm{hl}^{-1}$. Orchard: group of plots included in the same farm near to one another, and managed in similar ways by the same team of workers. Plot: group of trees usually belonging to the same cultivar, grown in the same field. NB: when a single plot includes a pollinating cultivar, or is planted with a mixture of varieties, if symptoms are detected on anyone of these varieties during blossom period, note 5 for IP. Blossom period: presence of insects: very active pollinating insects noticed in the plot. Postbloom: spraying required because a storm is foreseen: to be applied only if the storm passes over the plot; storm: any climatic event which is able to cause damage to trees (true storm, hail, violent wind, heavy rain); when spraying is required on secondary blossom: it has to be kept in mind that it is preferable to remove the flowers (open and appearing). If this is not feasible, a chemical spray should be applied.
Table VII. Table of decision during blossom period.

\begin{tabular}{|c|c|c|c|c|c|c|}
\hline \multirow[b]{2}{*}{$I P$} & \multicolumn{6}{|c|}{$C P$} \\
\hline & 1 & 2 & 3 & 4 & 5 & 6 \\
\hline 1 & $N$ & $\mathrm{~N}$ & $N$ & $\mathrm{~N}$ & V & V \\
\hline 2 & $\mathrm{~N}$ & $N$ & $N$ & $\mathbf{N}$ & V & $\mathrm{S}$ \\
\hline 3 & $\mathbf{N}$ & $\mathrm{N}$ & V & $V$ & $S$ & $S$ \\
\hline 4 & $N$ & $\mathrm{~N}^{*}$ & $V^{*}$ & $S$ & $S$ & $S$ \\
\hline 5 & $N^{*}$ & $S$ & $S$ & $\mathrm{~S}$ & $S$ & $S$ \\
\hline
\end{tabular}

*: spray if very active pollinating insects and symptoms are present in the orchard.

\section{DISCUSSION}

\section{Validity of the warnings}

This system has been used under different climatic situations in France over several years, either with past recorded climatic data, or with actual data and weather forecasts. Results of these experiments have been published else- 
Table VIII. Table of decision during postbloom period.

\begin{tabular}{llll} 
& \multicolumn{3}{c}{$C P$} \\
$I P$ & 1 & 2 & 3 \\
\hline & & & \\
1 & $N$ & $N$ & $N$ \\
2 & $N$ & $N / N^{*}$ & $V$ \\
3 & $N$ & $V$ & $S^{* *}$ \\
4 & $N$ & $S^{* *}$ & $S^{* \star}$ \\
\hline
\end{tabular}

* Only if secondary blossoms are present. ** And/or remove secondary blossoms.

where (Jacquart-Romon and Paulin, 1990). They lead to progressive improvements of the system which are included in this version. Other experiments are still in progress (Lecomte, personal communication). The general trends are the following:

- the warnings supplied by the system are in accordance with observed activity of the disease;

- when the results of different spray schedules have been compared (Jacquart-Romon and Paulin, 1990; Lecomte, personal communication), the advantage has constantly been in favour of the schedule based on computer warnings (fewer sprays for equal efficacy) as compared with a calendar-based schedule ( 3 sprays to protect the entire blossom period),

- on several occasions, the warning to visit an orchard has been found to be especially useful in allowing early detection of unpredictable symptoms (through an examination of rain and temperature data). These early detections are of the utmost interest when followed by a trimmingout of symptoms, because they may stop the inoculum supply for further infections during the rest of the year.

\section{Conditions of use}

The computer program has been devised for use on a compatible IBM PC personal microcomputer, a type of machine which is readily available and found in most places. Nevertheless, several conditions must be met before the proposed warning system can be used satisfactorily.

\section{Relation between climate and fire blight}

Several traits of our system are partly based on BOS. It should be underlined that a preliminary study was first carried out at several sites in France over a period of several years (past and actual climatic data), in order to obtain information on the validity of this system under our climatic conditions (Boué, 1984; Callu, 1984; Lecomte et al, 1984; Paulin et al, 1987). Such a study is probably essential before any attempt is made to use the warning system; although BOS has provided useful indications on fire blight development in several countries outside France (Poland, Canada, Belgium, The Netherlands) the same rules and parameter values may not be applied without adaptation in certain climates.

\section{Agreement between weather forecasts and actual climatic data}

Forecasts required to operate the system are included in a standard meteorological forecast except for the amount of rain. A special difficulty may arise with this rain-fall assessment, which is more difficult to predict than the simple occurrence of rain. This is the reason why the software includes an automatic test for alternative values regarding quantity of rain, and provides different warnings resulting from these values.

The available forecasts must be relevant for the site where the orchard to be protected is placed. This can be assessed quite easily through comparison between data collected in the orchard and information provided by the weather stations over several years. Climatic studies at the microclimate scale allow local meteorologists to provide forecasts relevant for the orchard.

The forecast of a general situation does not allow prevision of the occurrence of a stormy episode at any given site. To tackle this difficulty, it is recommended that the spray be applied only after the storm. Deckers and Porreye (1984) showed that such a "post-storm" spraying remained useful if applied immediately after the storm. The level of spraying efficacy was severely reduced if $>24 \mathrm{~h}$ had elapsed between storm and application of the spray.

\section{Collection of data}

The climatic data needed to operate the system are easy to collect, the ideal place to obtain them 
being the orchard. These data are required daily, and therefore a suitable device such as an automatic weather station connected to the telephone network could be very useful. Frequent visits to orchard are requested for determination of the inoculum potential.

\section{Inoculum level}

Although there is no direct experimental evidence for the relationship between visible symptoms and availability of bacteria, the description of the symptoms in the orchard remains the only reliable procedure to determine the inoculum level. Consequently it is essential to detect and examine the symptoms, and to collect as much data as possible on the local history of the disease. In addition, a survey of the orchard first in winter and then just before the beginning of the growth period is an absolute requirement.

Nevertheless, it may sometimes be difficult to decide whether or not lesions support bacterial multiplication. Further improvement may be expected in the precise definition of the localization of the symptoms (area, farm, plot) as well as in the knowledge of "infectivity" of the lesion (old overwintering lesion vs young extending symptoms). Besides, the determination of IP does not take into account the amount of visible symptoms. This is probably too simple an assessment of the inoculum level, but we have not been able to practically improve this input.

\section{Possibility and efficacy of interventions}

Finally, it should be pointed out that there is no need to operate a warning system if visits or sprays cannot be undertaken; the latter must be performed as soon as possible (within $24 \mathrm{~h}$ ) after warnings have been issued.

Chemicals for spraying against fire blight are now available (Garrett, 1990): streptomycin, where registered (USA, Canada, New Zealand, The Netherlands), flumequine (Firestop) in France and Belgium, copper compounds everywhere, when the risk of phytotoxicity can be controlled. Other compounds are likely to be available soon (ie Phosetyl-Al, Aliette). It is essential to be prepared to apply at least one of them when beginning to use the warning system, even though only the waring for visits and symptomdetection already provides very useful assistance in fire blight control.
The period during which the chemical remains effective after it has been sprayed on the plant is variable; it depends on the characteristics of the chemical, the phenological stage of the plant, and the climate. It is generally accepted that a cumulative $25 \mathrm{~mm}$ rainfall is enough to wash out a chemical from the plant surface. This threshold is taken into account in the warning system. Furthermore, tree growth results in the exposure of new, unprotected sites on the surface of leaves and other organs. The following intervals between sprays are therefore recommended: $3 \mathrm{~d}$ during the period of fast opening of flowers, $5 \mathrm{~d}$ during the steady blossom period, and $15 \mathrm{~d}$ during postbloom.

\section{CONCLUSION}

The value of such a computerized system lies in the balance between inputs and the outputs. Inputs must be relevant, precise, but at the same time easy to collect at the proper scale (ie the orchard level), reliable and inexpensive to obtain. Outputs must provide an obvious advantage when compared with any other method of decision.

In the warning system presented here, it seems that these requirements are satisfactorily met, although it is likely that improvements can be obtained through further experimentation and observations on the disease. Besides, the system as it stands does not use the available data on shoot and blossom susceptibility of pear and apple trees (Thibault and Le Lezec, 1990). The integration of this data in the warning system would undoubtedly improve its accuracy.

The Billing approach (BOS) used as a basis for our warning system has been revised recently (Billing, 1990) as BRS; the underlying rationale is similar, but several changes have been made, mainly concerning calculation of PD values from temperatures, which affect the length of incubation periods, and the climatic conditions required for infections (temperature- and/or rainbased). BRS has not been tested as a basis for our warning system. Nevertheless, experiments are presently being carried out in several places in France comparing BRS and BOS. The threshold values for temperature and rain taken into account in the warming system are checked by the agreement of BOS with the epidemiological data on fire blight in France: the incorporation in the warning system of concepts based on BRS would imply the evaluation of new ade- 
quate thresholds. This could be relevant in conditions where BOS does not give satisfactory results.

The information required by the software is picked up on the local scale: this applies for climatic as well as for inoculum potentials. "Local" can be defined as the plot or the orchard, or a homogeneous group of orchards of the same variety in an area where climatic features are fairly constant. Similarly, climatic forecasts will not be relevant for very wide areas: these facts imply that the proposed system is not devised for large areas, such as a production zone. On the contrary, it must be used at the orchard level. Under these conditions, it will provide simple but efficient help in the control of fire blight, thus avoiding mistakes and giving clear guidelines on what is likely to be the best strategy of control to follow in a given orchard. Its commercial availability to growers and plant protection services is presently under study.

\section{ACKNOWLEDGMENTS}

We thank $E$ Billing for fruitful discussions in the course of this work, P Lecomte, JC Lalande, from INRAAngers, $F$ Roger and $P$ Larue from SRPV, Paris and Dax for efficient testing of the system in the field. We acknowledge the help of MC Roland in reviewing the manuscript. Special thanks are due to $E$ de Loménie.

\section{REFERENCES}

Bazzi C, Gasser M, Mazzucchi U (1984) Weather analysis with Billing's spring system in relation to the potential risk of fire blight outbreaks in Italy. Acta Hortic 151, 97-106

Beer SV, Schwager SJ, Norelli JL, Aldwinckle HS, Burr TJ (1984) Towards a practical warning system for fire blight blossom infections. Acta Hortic 151, 23-36

Billing $E$ (1976) Weather and fire blight in England. Ann Appl Biol 82, 259-266

Billing $\mathrm{E}$ (1978a) Developments in fire blight prediction in south-east England. In: Plant Disease Epidemiology (Scott PR, Brainbridge A, eds) Blackwell Sci Publ, Oxford, 159-166

Billing $E$ (1978b) The assessment of the potential for fire blight activity from daily temperature and rainfall data In: Proc 4th Inf Conf Plant Path Bact, Angers, August 27-September 2, 1978 INRA, Angers, France, Vol II (Abstr), 523-524

Billing $E$ (1979) Fire blight: the development of a predictive system. In: Plant Pathogens (Lovelock DW, ed) Academic Press, London, 51-59
Billing $E$ (1980a) Fire blight in Kent, England, in relation to weather (1955-1976). Ann Appl Biol 95, 341-364

Billing $E$ (1980b) Fire blight (Erwinia amylovora) and weather: a comparison of warning systems. Ann Appl Biol 95, 365-377

Billing $E$ (1984) Principles and applications of fire blight risk assessment systems. Acta Hortic 151, $15-22$

Billing $E$ (1988) Developments in fire blight risk assessment. Aspects Appl Biol 17, 255-256

Billing $E$ (1990) Fire blight concepts and a revised approach to risk assessment. Acta Hortic 273, 163170

Billing E, Paulin JP (1990) The development of fire blight risk assessment approaches in Europe. In: Fire Blight of Pomoidea (1978-1988). Eur 12601. ECSC-EEC-EAEC, Brussels, 20-33

Bonn WG (1987) Potential for fire blight activity in Ontario. Acta Hortic 217, 101-112

Boué $H$ (1984) Climate and fire blight in the Garonne valley (1978-1982). Acta Hortic 151, 107-112

Callu D (1984) Situation du feu bactérien en France (1982-1983). Acta Hortic 151, 317-323

Deckers T, Porreye W (1984) Chemical control of Erwinia amylovora Burrill, Winslow et al in pear orchards. Acta Hortic 151, 215-221

Fleckinger J (1945) Notations phénologiques et représentations graphiques du développement des bourgeons du poirier. CR Congr Assoc Fr Av Sci (Paris) 73, 91-98

Garrett CME (1990) Control of fire blight. In: Fire Blight of Pomoideae (1978-1988). Eur 12601. ECSCEEC-EAEC, Brussels, 54-78

Jacquart-Romon C, Paulin JP (1990) Preliminary experimentation of a computerized warning system for the control of fire blight. Acta Hortic 273, 131-137

Jacquart-Romon C, Paulin JP, Payen D (1984) Climatic assessment of the risks of fire blight at bloom. Acta Hortic 151, 129-135

Jacquart-Romon C, Payen D, Paulin JP (1987) A computer program based on Billing's system 1 for timing of control measures against fire blight. Acta Hortic $217,119-123$

Lecomte P, Larue P, Paulin JP (1984) Climate and fire blight in the Dax area (1977-1982). Acta Hortic $151,113-119$

Meijnecke CAR, Van Teylingen M (1981) The development of fire blight in the Netherlands during 1979 and its explanation by the system Billing. Acta Hortic 117, 25-30

Mills WD (1955) Fire blight development on apple in western New York. Plant Dis Rep 39, 206-207

Paulin JP, Lecomte $P$, Boué $M$, Callu $D$, Larue $P$ (1983) Climat et feu bactérien : essai d'application du «système 1 » de Billing dans les conditions françaises. Bull OEPP/EPPO Bull 13 (2), 283-289 
Paulin JP, Lachaud G, Chartier R (1987) Results of spray experiments on the control of fire blight. Acta Hortic 217, 239-242

Powell D (1965) Factors influencing the severity of fire blight infections on apple and pear. Mich State Hortic Soc Am Mtg Rpt 94, 1-7

Sobiczewski P (1984) Study on fire blight forecasting. Acta Hortic 151, 91-95

Steiner WP (1990a) Predicting apple blossom infections by Erwinia amylovora using the MARYBLIT model. Acta Hortic 273, 139-148

Steiner WP (1990b) Predicting cankers, shoot and trauma blight phases of apple fire blight epidermics using the MARYBLIT model. Acta Hortic 273, 149-158
Thibault B, Le Lezec M (1990) Sensibilité au feu bactérien des principales variétés de pommier et de poirier utilisées en Europe. In: Fire Blight of Pomoideaes (1978-1988). Eur 12601. ECSC-EECEAEC, Brussels, 96-109

Thomson SV, Schroth MN, Moller WJ, Reil WO (1975) Occurrence of fire blight of pears in relation to weather and epithytic populations of Erwinia amylovora. Phytopathology 65, 353-358

Thomson SV, Schroth MN, Moller WJ, Reil WO, Beutel JA, Davis CS (1977) Pesticide applications can be reduced by forecasting the occurrence of fire blight bacteria. Erwinia amylovora on pears. Calif Agric 31 (10), 12-14 